GRASAS Y ACEITES 68 (3)

July-September 2017, e201

ISSN-L: 0017-3495

doi: http://dx.doi.org/10.3989/gya.1278162

\title{
Butylated caffeic acid: An efficient novel antioxidant
}

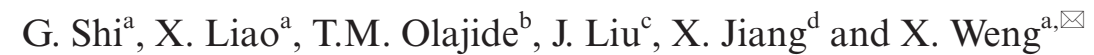 \\ a,b,c,d School of Life Sciences, Shanghai University 333, Nanchen Road, Shanghai, 200444, China \\ Corresponding author: weng_xinchu@sina.com; wxch@staff.shu.edu.cn
}

Submitted: 29 December 2016; Accepted: 20 March 2017

SUMMARY: A novel antioxidant, butylated caffeic acid (BCA) was rationally designed by adding a tertbutyl group to caffeic acid, which was synthesized at a high yield (36.2\%) from 2-methoxy-4-methylphenol (1) by a four-step reaction including Friedel-Crafts alkylation, bromine oxidation, ether bond hydrolysis and Knoevenagel condensation. Its antioxidant capacity was much stronger than common commercial antioxidant tert-butyl hydroquinone (TBHQ) and its mother compound, caffeic acid, in both rancimat and deep frying tests. When investigated via the DPPH method, the antioxidant capacity of BCA was almost equal to TBHQ, but lower than caffeic acid. BCA could be a potentially strong antioxidant, especially for food processing at high temperatures such as deep frying and baking.

KEYWORDS: Antioxidant capacity; Butylated caffeic acid; Deep frying

RESUMEN: Ácido cafeico butilado: un nuevo y eficaz antioxidante. Se diseñó razonadamente un nuevo antioxidante, el ácido cafeico butilado (BCA) mediante la adición de un grupo terc-butilo al ácido cafeico, que se sintetizó con un alto rendimiento $(36,2 \%)$ a partir de 2-metoxi-4-metilfenol, reacción de Friedel-Crafts, oxidación de bromo, hidrólisis del enlace éter y condensación de Knoevenagel. Su capacidad antioxidante fué mucho más fuerte que la del antioxidante comercial mas común el terc-butil hidroquinona (TBHQ) y la de su compuesto madre el ácido cafeico, tanto en rancimat como en pruebas de fritura. Cuando se investigó mediante el método DPPH, la capacidad antioxidante de BCA fue casi igual a TBHQ, pero menor que la del ácido cafeico. BCA podría ser un fuerte antioxidante potencial, especialmente para el procesamiento de alimentos a alta temperatura, tales como freír y hornear.

PALABRAS CLAVE: Ácido cafeico butilado; Capacidad antioxidante; Fritura

ORCID: Shi G http://orcid.org/0000-0003-0391-9525, Liao X http://orcid.org/0000-0003-1394-1160, Olajide TM http://orcid.org/0000-0003-4751-8715, Jiang X http://orcid.org/0000-0003-1171-014X, Liu J http://orcid.org/00000002-3456-4598, Weng X http://orcid.org/0000-0003-2047-1654

Citation/Cómo citar este artículo: Shi G, Liao X, Olajide TM, Liu J, Jiang X, Weng X. 2017. Butylated caffeic acid: an efficient novel antioxidant. Grasas Aceites 68 (3), e201. http://dx.doi.org/10.3989/gya.1278162

Copyright: (C2017 CSIC. This is an open-access article distributed under the terms of the Creative Commons Attribution (CC-by) Spain 3.0 License. 


\section{INTRODUCTION}

As widely known, dietary lipids are highly acceptable by consumers because of the palatability, typical smell and taste of their products. They play an important role in food nutrition and flavor during processing. Meanwhile, the exposure of lipids to air triggers their autoxidation, giving rise to rancid odors and flavors, with the decomposition of nutritional components (flavors, essential amino acids, fat-soluble vitamins, etc.), formation of secondary oxidation products and reduction in food safety. Lipid oxidation is one of the main causes of food quality deterioration, with the production of aldehydes, ketones, alcohols, hydrocarbons, volatile organic acids, and epoxy compounds. With an adequate understanding of how this oxidative degradation actually takes place in fats and oils, it has been determined that the autoxidation of unsaturated fatty acids occurs via a free radical chain reaction, including initiation, propagation, and termination.

Currently, with the brief background on how oxidation takes place in lipids, many efforts such as biological, physical, and chemical methods have been made to reduce oxidation (Akoh and Min, 2008). The best method, however, is still the addition of strong antioxidants to prevent the deterioration of lipids (Chen and Ho, 1995; Rojas and Brewer, 2007).

Among the commercial antioxidants, TBHQ is frequently applied during deep frying due to its low price and effective antioxidant capacity (Shahidi et al., 1992). TBHQ, an aromatic organic phenol, is chemically synthesized. It is a derivative of hydroquinone, substituted with a tert-butyl group, and has good solubility in lipids (Emerton and Choi, 2008). The maximum level of TBHQ allowed in a finished product like frozen fish stored for 14 weeks is $120 \mathrm{mg} / \mathrm{kg}$ (Hsieh and Regenstein, 1991). The addition of TBHQ in lipids does not cause discoloration even when irons are present, and does not change the flavor or odor of the material. In addition, TBHQ is effective at early storage times in lengthening the induction period before oxidation is initiated, though it is not effective for baked food applications (Emerton and Choi, 2008; Hsieh and Regenstein, 1992).

The antioxidant capacity of TBHQ, however, decreases after a while because of the following reasons: It is absorbed by fried products; it evaporates under high temperature due to its low molecular weight (Hwang et al., 2013). Other disadvantages include being questioned for possible negative sideeffects in humans (Van Esch, 1986).

As a natural antioxidant, caffeic acid (3,4-dihydroxycinnamic acid) has been studied in many reports. It is among the major hydroxycinnamic acids present in wine. It shows not only a good biological activity with known antiviral, anti-inflammatory, anticancer properties and heart protecting effects, but also an efficient antioxidant capacity in vitro, which has also been utilized extensively as a potent antioxidant (Gülçin, 2006). However, caffeic acid exhibits poor solubility in oils due to its carboxyl group, which decreases its fat-solubility in practice.

It is highly desirable to develop a new antioxidant of better lipid solubility than caffeic acid with antioxidant capacity as strong as BCA (butylated caffeic acid, or systematic nomination: (E)-3-(3(tert-butyl)-4,5- dihydroxyphenyl) acrylic acid), which could be utilized for food preservation. This study is aimed at investigating the structural modification of caffeic acid via its alkylation and examining its antioxidant activity in food processing.

The modification of structures such as polyphenolic compounds increases their solubility in oils, and speeds up the leaving out of ortho-hydrogen, thereby, improving antioxidant capacity in oils (Huang et al., 2014; Zhang et al., 2004). Hence, structural modification is a convenient and efficient method that can be employed to improve the solubility of caffeic acid in oils by adding long-chain alkanes or the tert-butyl group at the ortho-aromatic ring, without decreasing phenol hydrogens.

Considering the steric hindrance effect and lipid solubility, the influence of the tert-butyl group is better than long-chain alkanes. At first, the tertbutyl group was added to the ortho-aromatic ring directly through Friedel-Crafts alkylation reaction from caffeic acid, although it proved abortive after a series of experimental condition alterations such as material ratio, temperature, the pattern of material addition and solvents. It could be that the density of electrons in benzene decreased because of the location-based effects of the acrylic acid group. Therefore, two main steps were devised: the tertbutyl group was added to the main body of benzene without location-based effects and then it was conjugated by the group of acrylic acid.

\section{MATERIALS AND METHODS}

\subsection{Materials}

Lard was rendered in the laboratory and stored at $-18{ }^{\circ} \mathrm{C}$ for use. Commercial soybean oil was purchased from Wilmar International Limited (Shanghai, China). Potatoes were purchased from a local market. Other chemicals were obtained from Sinopharm Chemical Reagent Co. Ltd. The solvents employed were of AR grade.

All of the reactions were monitored by thin-layer chromatography (TLC) performed on silica gel $\mathrm{GF}_{254}$ (homemade). Ultraviolet (UV) spectra were recorded with a UV-2450 spectroscopic instrument (Shimadzu Corp, Kyoto, Japan). The quartz cell was used as a vessel. The protection factors for antioxidants were measured by the rancimat method (Metrohm, Shanghai, China). All NMR experiments were conducted on a Bruker Avance $500 \mathrm{MHz}$ spectrometer 
(Bern, Switzerland) operating at $500.1 \mathrm{MHz}$ for ${ }^{1} \mathrm{H}$ and $125.8 \mathrm{MHz}$ for ${ }^{13} \mathrm{C}$, respectively. Chemical shifts were reported in ppm using TMS as internal standard. The single-crystal structure analysis was performed using X-ray diffraction on a Bruker Smart Apex II diffractometer (Germany) at $296 \mathrm{~K}, \mu(\mathrm{Cu} /$ $\mathrm{K} \alpha)=0.108 \mathrm{~mm}^{-1}$, Dcalc $=1.354 \mathrm{mg} / \mathrm{m}^{3}, 5584$ reflections were measured, 1935 were unique $(\operatorname{Rint}=0.0147)$. The structure was dissolved with SheLXS a structure solution program using Direct methods and refined with SheLXL refinement package using least squares minimization (Zhou et al., 2016).

The samples were examined in duplicate. Pearson's correlation test and t test were conducted using Origins 8 (Origin Lab, MA, United States). Reported data show standard deviation below 5\%. Statistical significance has $\mathrm{p}$ values always below 0.05 .

\subsection{General synthesis of BCA}

The compounds 2-4 were prepared according to earlier methods (Saiz-Poseu et al., 2012; Wang et al., 2006) with slight modifications (Scheme 1).

\section{Preparation of 2-(tert-butyl)-6-methoxy-4-methylphe-} nol (2): $7.80 \mathrm{~mL}$ of 2-methoxy-4-methylphenol (1) (61.7 mmol, 1 equiv) were added to $85 \%$ phosphoric acid $(19 \mathrm{ml})$ and tert-butanol $(30 \mathrm{ml}, 328.4 \mathrm{mmol}, 5.32$ equiv) at $90{ }^{\circ} \mathrm{C}$. After stirring for 7 hours, and concentrated to remove most of the tert-butanol under reduced pressure, ethyl acetate $(100 \mathrm{~mL})$ and water $(10 \mathrm{~mL})$ were added. The organic phase was dried over $\mathrm{Na}_{2} \mathrm{SO}_{4}$ and concentrated under reduced pressure. The crude products were purified with flash chromatography (petroleum ether:ethyl acetate $=20: 0.5$ ) to yield $\mathbf{2}$, a light, colorless oil $(8.50 \mathrm{~g}, 71 \%) .{ }^{1} \mathrm{H}$ NMR $(500 \mathrm{MHz}$, $\left.\mathrm{CDCl}_{3}, \mathrm{ppm}\right) \delta 1.49(\mathrm{~s}, 9 \mathrm{H}), 2.37$ (s, 3H), $3.93(\mathrm{~s}, 3 \mathrm{H})$, $5.91(\mathrm{~s}, 1 \mathrm{H}), 6.67(\mathrm{~s}, 1 \mathrm{H}), 6.78(\mathrm{~d}, \mathrm{~J}=0.35 \mathrm{~Hz} .2 \mathrm{H}) .{ }^{13} \mathrm{C}$ NMR (125.8 MHz, $\left.\mathrm{CDCl}_{3}, \mathrm{ppm}\right) \delta 21.53,29.56,34.67$, $56.14,109.423,127.92,135.24,142.01,146.55$.

Preparation of 3-(tert-butyl)-4-hydroxy-5-methoxybenzaldehyde (3): $3.00 \mathrm{~g}$ of compound 2 (15.5 mmol, 1 equiv) were added to tert-butanol $(35 \mathrm{~mL})$, stirred at $0{ }^{\circ} \mathrm{C}$, then liquid bromine $(2.5 \mathrm{ml}, 48.7 \mathrm{mmol}, 3.14$ equiv) was added drop-wise, under nitrogen atmosphere for 20 minutes, while keeping the solution pink. After the addition, the mixture was stirred at room temperature for $1 \mathrm{~h}$, quenched by $50 \mathrm{ml} \mathrm{H}_{2} \mathrm{O}$ and then partitioned with $50 \mathrm{ml}$ ethyl acetate. The organic phase was dried over $\mathrm{Na}_{2} \mathrm{SO}_{4}$ and concentrated under reduced pressure. The crude products were purified with flash chromatography (petroleum ether: ethyl ether $=13: 1)$ to yield 3, a light, yellow solid $(2.6 \mathrm{~g}$, $80 \%),{ }^{1} \mathrm{H}$ NMR $\left(500 \mathrm{MHz}, \mathrm{CDCl}_{3}, \mathrm{ppm}\right) \delta 1.44(\mathrm{~s}$, $9 \mathrm{H}), 3.97(\mathrm{~s}, 3 \mathrm{H}), 6.64(\mathrm{~s}, 1 \mathrm{H}), 7.34(\mathrm{~d}, \mathrm{~J}=1.65 \mathrm{~Hz}, 1 \mathrm{H})$, $7.47(\mathrm{~d}, \mathrm{~J}=1.65 \mathrm{~Hz} .2 \mathrm{H}) .9 .84$ (s, 1H). ${ }^{13} \mathrm{C}$ NMR $(125.8$ $\left.\mathrm{MHz}, \mathrm{CDCl}_{3}, \mathrm{ppm}\right) \delta 29.14,34.70,56.33,106.79$, $125.34,128.30,135.65,147.25,150.41,191.52$.

Preparation of 3-(tert-butyl)-4,5-dihydroxybenzaldehyde (4): $2.00 \mathrm{~g}$ of compound $\mathbf{3}$ (9.6 mmol, 1 equiv) were dissolved in $\mathrm{CHCl}_{3}(20 \mathrm{~mL})$, and stirred at $0{ }^{\circ} \mathrm{C}$. After, $\mathrm{AlCl}_{3}(1.79 \mathrm{~g}, 13.5 \mathrm{mmol}, 1.4$ equiv) was added in batches and then pyridine $(3.4 \mathrm{~mL}, 42.3 \mathrm{mmol}$, 4.4 equiv) was added drop-wise. The mixture was refluxed for $24 \mathrm{~h}$, cooled down to $0{ }^{\circ} \mathrm{C}$ and washed with $10 \% \mathrm{HCl}(60 \mathrm{~mL} \times 3)$ until the aqueous phase became light blue. It was then was partitioned with $150 \mathrm{ml}$ ethyl acetate. The organic phase was dried over $\mathrm{Na}_{2} \mathrm{SO}_{4}$ and concentrated under reduced pressure. The crude products were purified with flash chromatography (petroleum ether: ethyl ether $=4: 1$ ) to yield 4, a white powder $(1.4 \mathrm{~g}, 75 \%),{ }^{1} \mathrm{H}$ NMR $(500 \mathrm{MHz}$, acetone- $\left.\mathrm{d}_{6}, \mathrm{ppm}\right) \delta 1.46(\mathrm{~s}, 9 \mathrm{H}), 7.31(\mathrm{~d}, \mathrm{~J}=1.8 \mathrm{~Hz}$, $1 \mathrm{H}), 7.44(\mathrm{~d}, \mathrm{~J}=1.8 \mathrm{~Hz}, 1 \mathrm{H}), 9.78(\mathrm{~s}, \mathrm{H}) .{ }^{13} \mathrm{C}$ NMR (125.8 MHz, acetone-d $\left.{ }_{6}, \mathrm{ppm}\right) \delta 28.71,34.44,111.56$, $122.79,128.48,135.96,144.99,150.48,190.80$.

Preparation of BCA: $1.00 \mathrm{~g}$ of 3-(tert-butyl)-4,5-dihydroxybenzaldehyde (4) $(5.2 \mathrm{mmol}, 1$ equiv) and malonate $(0.54 \mathrm{~g})$ were dissolved in a mixture of benzene $(5 \mathrm{ml})$, pyridine $(0.6 \mathrm{ml}, 5.2 \mathrm{mmol}, 1$ equiv) and piperidine ( $0.06 \mathrm{~mL}, 0.7 \mathrm{mmol}, 0.13$ equiv). The solution was stirred at refluxing temperature for $3.5 \mathrm{~h}$, cooled to $25{ }^{\circ} \mathrm{C}$, poured into the mixture of conc. $\mathrm{HCl}_{(\mathrm{ag})}$ and ice water, and then was partitioned with ethyl acetate $(20 \mathrm{ml})$. The organic phase was dried over $\mathrm{Na}_{2} \mathrm{SO}_{4}$ and concentrated under reduced pressure. The crude products were purified with flash chromatography (petroleum ether: ethyl ether $=3: 2$ ) to yield $\mathbf{5}$ (BCA) $(1.04 \mathrm{~g}, 85 \%)$, which was re-crystallized from methanol to afford needle-like light beige crystals, ${ }^{1} \mathrm{H}$ NMR $\left(500 \mathrm{MHz}\right.$, acetone-d $\left.\mathrm{d}_{6}, \mathrm{ppm}\right) \delta 1.45(\mathrm{~s}, 9 \mathrm{H})$, $6.24(\mathrm{~d}, \mathrm{~J}=15.85 \mathrm{~Hz}, 1 \mathrm{H}), 7.10(\mathrm{~d}, \mathrm{~J}=1.85 \mathrm{~Hz}, 2 \mathrm{H}), 7.57$ $(\mathrm{J}=15.85 \mathrm{~Hz}, 1 \mathrm{H}) \cdot{ }^{13} \mathrm{C}$ NMR $\left(125.8 \mathrm{MHz}\right.$, acetone- $\mathrm{d}_{6}$, ppm) $\delta 28.86,34.41,111.39,114.19,120.16,125.08$, 136.00, 144.79, 147.13, 147.00, 168.07.

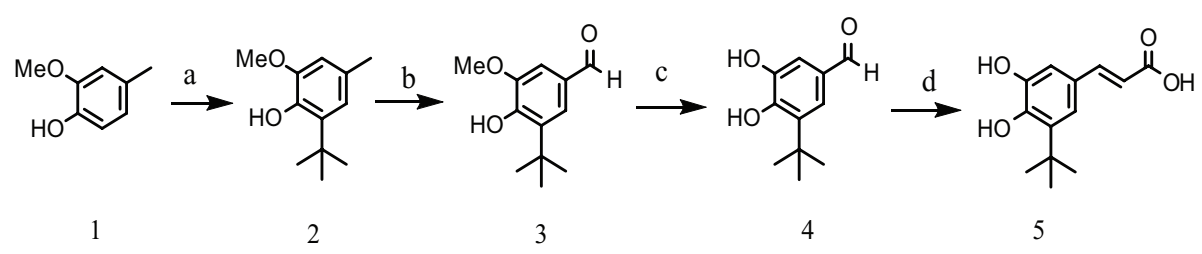

SCHEME 1. Reagents and conditions: a) t-BuOH, $85 \% \mathrm{H}_{3} \mathrm{PO}_{4}, 90{ }^{\circ} \mathrm{C}, 7 \mathrm{~h}, 71 \%$; b) $\mathrm{Br}_{2}, \mathrm{t}-\mathrm{BuOH}, \mathrm{rt}, 1 \mathrm{~h}, 80 \%$; $) \mathrm{AlCl}$, pyridine, $\mathrm{CHCl}_{3}, 75 \%$; d) piperidine, pyridine, $90^{\circ} \mathrm{C}, 24 \mathrm{~h}, 85 \%$. 


\subsection{Deep frying analysis}

Commercial soybean oil was purified by silica gel column chromatography to remove its endogenous antioxidants. Different $0.02 \%(\mathrm{w} / \mathrm{w})$ antioxidants were added to soybean oil samples (500 g) separately and then the oil samples were heated to $180{ }^{\circ} \mathrm{C}$. Fresh potato slices, about $2 \pm 0.5 \mathrm{~mm}$ thickness, were added at the rate of $20 \mathrm{~g} / \mathrm{h}$, fried for 8 minutes, then removed from the oils. Oil samples were tested every $3 \mathrm{~h}$ during the frying period until $60 \mathrm{~h}$. Acid values (AV) and Iodine values (IV) were determined for each sample using the International Union of Pure and Applied Chemistry (IUPAC) method (Paquot and Hautfenne, 1987).

The CD values were calculated from the absorbance and the final concentration of the samples $(\mathrm{g} / 100 \mathrm{~mL})$. The results were expressed as conjugated diene (CD) values and computed as follows (Glende and Recknagel, 1994; Zuta et al., 2007):

$$
C D=\frac{A}{C} * P
$$

Where, A is absorbance of the sample at $233 \mathrm{~nm}$. $\mathrm{C}$ is final dilution concentration of the sample $(\mathrm{g} / 100 \mathrm{~mL})$.

$\mathrm{P}$ is the length of the measuring $\mathrm{UV}$ cell $(\mathrm{cm})$.

\subsection{Rancimat analysis}

The antioxidant capacities of BCA, TBHQ and caffeic acid were measured by the rancimat method (Metrohm, Shanghai, China) at different concentrations in oils. An air flow $(20 \mathrm{~L} / \mathrm{h})$ was bubbled through the oil heated at different temperatures: 80,100 and $120^{\circ} \mathrm{C}$. The tests were carried out in duplicate. The protection factors (Pf) were calculated according to the following formula (Silva et al., 2001):

$$
\mathrm{Pf}=\frac{I P_{x}}{I P_{0}}
$$

Where, $I P_{\mathrm{x}}=$ the induction period of the sample in the presence of antioxidant.

$I P_{0}=$ the induction period of the sample without antioxidant.

\subsection{DPPH spectrophotometric assay}

A $0.5 \mathrm{~mL}$ methanol solution of different antioxidant concentrations was added to a DPPHmethanol solution $(3.0 \mathrm{~mL}, 40 \mathrm{mg} / \mathrm{L})$, and allowed to react for $30 \mathrm{~min}$ at $25^{\circ} \mathrm{C}$, then, absorbance at $517 \mathrm{~nm}$ was recorded at different time intervals on a UV visible spectrophotometer. The DPPH concentration in the reaction medium was calculated from the calibrated curve. The radical scavenging activity $(\%)$ was calculated according to the following formula (Liu et al., 2014; Piang-Siong et al., 2017):

Scavenging activity $(\%)=1-\frac{\left(\mathrm{A}_{\text {sample }}-A_{\text {blank }}\right)}{\mathrm{A}_{\text {control }}} * 100 \%$

A DPPH solution (3 $\mathrm{mL})$ with methanol $(0.5 \mathrm{~mL})$ was used as negative control. A solution $(3 \mathrm{~mL})$ with methanol $(0.5 \mathrm{~mL})$ with a different concentration of antioxidant was used as a blank. $\mathrm{EC}_{50}$ (i.e., efficient concentration of the substance that produces $50 \%$ scavenging), obtained for the different antioxidants was calculated by linear regression of plots, where radical scavenging activity (\%) was plotted against concentration.

\section{RESULTS}

\subsection{Chemical structure of $\mathrm{BCA}$}

The ${ }^{1} \mathrm{H}$ and ${ }^{13} \mathrm{C}$ chemical shifts of compound BCA agree well with its chemical structure, which is compared with the spectra data for caffeic acid reported in the literature (Jeong et al., 2011).

The single-crystal structure analysis of BCA was performed using X-ray diffraction. The crystal data of BCA presented (Figure 1; Table 1) give the perspective views of this compound together with its atomic labelling system. Thus, it can be confirmed for the absolute configuration of BCA ((E)-3-(3-(tert-butyl)-4,5-dihydroxyphenyl) acrylic acid).

\subsection{Antioxidant capacity in deep frying oil}

During the oxidation of lipids containing methylene substituted dienes and polyenes, a shift in the position of the double bond was observed, due to isomerization and conjugated bond formation (conjugated dienes). The percentage changes of $\mathrm{CD}$ during frying (Figure 2, A), were as follows: BCA $>$ Caffeic acid $>$ TBHQ $>$ Blank.

No obvious change was observed during the initial 12 hours (Figure 2, B). But, later, the change in $\mathrm{AV}$ manifested the capacity of antioxidants as follows: CBA > Caffeic acid>TBHQ $>$ Blank.

When soybean oils were in deep frying at $180^{\circ} \mathrm{C}$, some polyunsaturated fatty acids became conjugated, and some double bonds were destroyed, thus, decreasing iodine values. IV changes at $180^{\circ} \mathrm{C}$ (Figure 2, C) increased as follows: BCA $>$ Caffeic acid $>$ TBHQ $>$ Blank. 

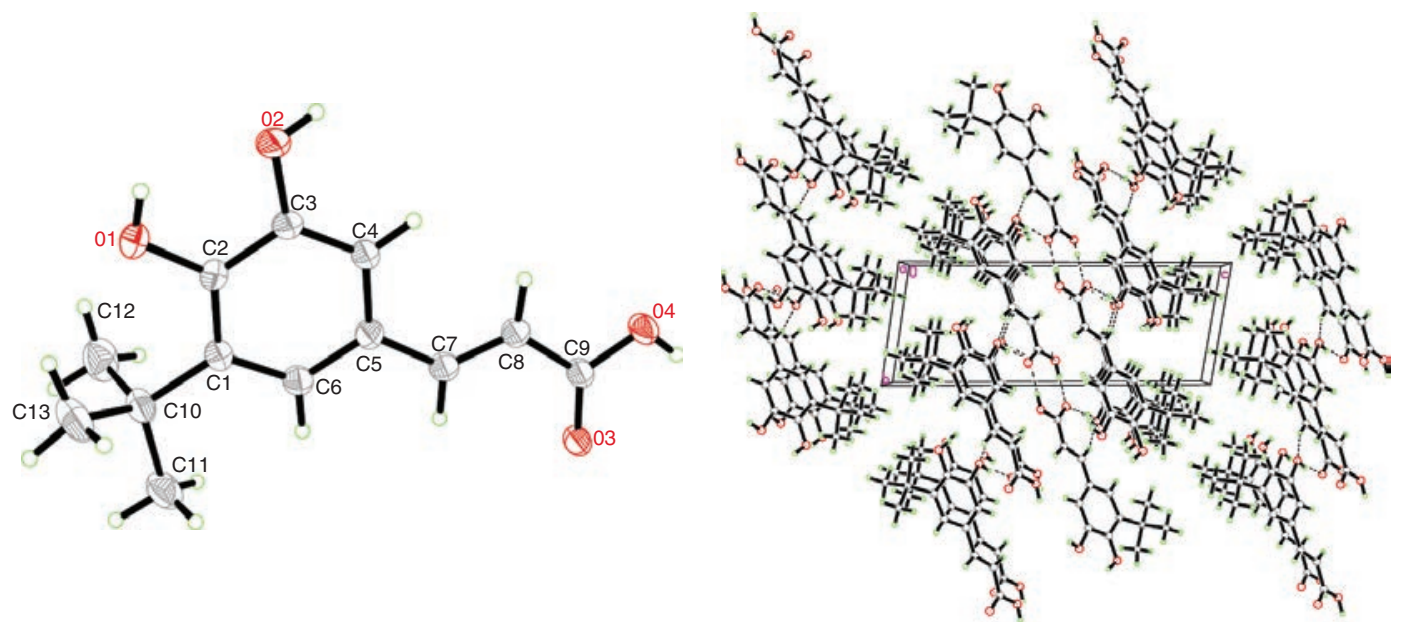

FIGURE 1. Crystal structure diagram of BCA by X-ray diffraction.

TABLE 1. Crystal Data and Structure Refinement for BCA

\begin{tabular}{|c|c|}
\hline Empirical formula & $\mathrm{C}_{13} \mathrm{H}_{16} \mathrm{O}_{4}$ \\
\hline formula weight & 236.26 \\
\hline temperature $(\mathrm{K})$ & $296(2)$ \\
\hline crystal system & triclinic \\
\hline space group & P-1 \\
\hline $\mathrm{a}(\AA)$ & $6.037(3)$ \\
\hline $\mathrm{b}(\AA)$ & $6.357(3)$ \\
\hline c $(\AA)$ & $16.711(9)$ \\
\hline $\mathrm{v}(\AA)$ & $618.7(6)$ \\
\hline $\mathrm{z}$ & 2 \\
\hline$\rho_{\text {caldd }}\left(\mathrm{mg} / \mathrm{m}^{3}\right)$ & 1.268 \\
\hline$\mu(\mathrm{Mo} / \mathrm{Ka})\left(\mathrm{mm}^{-1}\right)$ & 0.094 \\
\hline $\mathrm{F}(000)$ & 252 \\
\hline crystal size $\left(\mathrm{cm}^{3}\right)$ & $0.23 \times 0.20 \times 0.20$ \\
\hline reflections collected/unique & $3216 / 2157$ \\
\hline $\mathrm{R}_{\text {int }}$ & 0.0118 \\
\hline data/restraints/parameters & $2157 / 0 / 161$ \\
\hline goodness-of-fit on $\mathrm{F}^{2}$ & 1.050 \\
\hline $\mathrm{R}_{1}, \mathrm{wR}_{2}[\mathrm{I}>2 \sigma(\mathrm{I})]$ & $0.0394,0.1033$ \\
\hline $\mathrm{R}_{1}, \mathrm{wR}_{2}$ (all data) & $0.0498,0.1149$ \\
\hline
\end{tabular}

\subsection{Antioxidant capacity using the rancimat method}

According to their Pf values (Figure 3), TBHQ, Caffeic acid and BCA showed good antioxidant capacities in the concentration $0.02 \%$ at 80, 100, and $120{ }^{\circ} \mathrm{C}$, as follows: $\mathrm{BCA}>$ Caffeic acid $>$ TBHQ $>$ Blank.

In different concentrations, $0.01,0.02$, and $0.04 \%$ at $100{ }^{\circ} \mathrm{C}$ (Figure 4), Pf values changed as follows: BCA $>$ Caffeic acid $>$ TBHQ $>$ Blank. BCA, however, showed a remarkable Pf value (i.e., 79.9) at a concentration of $0.04 \%$ at $100^{\circ} \mathrm{C}$.

\subsection{Antioxidant capacity using DPPH spectrophotometric assay}

The scavenging DPPH radical is widely used to evaluate antioxidant capacity due to its simple, rapid, sensitive and reproducible procedure. In this study, kinetic investigation was performed to estimate the speed of DPPH-Antioxidant reaction. On the other hand, $\mathrm{EC}_{50}$ of TBHQ, caffeic acid and BCA were measured in terms of hydrogen-donating or radical-scavenging capacity.

The $\mathrm{EC}_{50}$ values for the reducing power of TBHQ, Caffeic acid and BCA were 0.1690, 0.1283, and $0.1748 \mu \mathrm{g} / \mathrm{L}$, respectively. The reducing power decreased as follows:

TBHQ $\approx \mathrm{BCA}>$ Caffeic acid. The ease of donating hydrogen (Figures 5, A and B) was Caffeic acid $>\mathrm{TBHQ} \approx \mathrm{BCA}$.

\section{DISCUSSION}

\subsection{Antioxidant capacity of BCA in deep frying oils and rancimat test}

In the deep frying oil and rancimat tests, BCA showed stronger antioxidant capacity than TBHQ and caffeic acid (Scheme 2):

1. The influence of the tert-butyl group: Increased the grease compatibility and the leaving out of ortho-hydrogens on BCA (Huang et al., 2014), at $180{ }^{\circ} \mathrm{C}$.

2. The influence of the acrylic acid group: Enlarged the conjugation system, which provided more stabilized radical resonance to capture more peroxyl radicals. It also benefited the intermolecular coupling of BCA to form a large relative molecular mass (Figure 1), with a higher boiling point than TBHQ. 

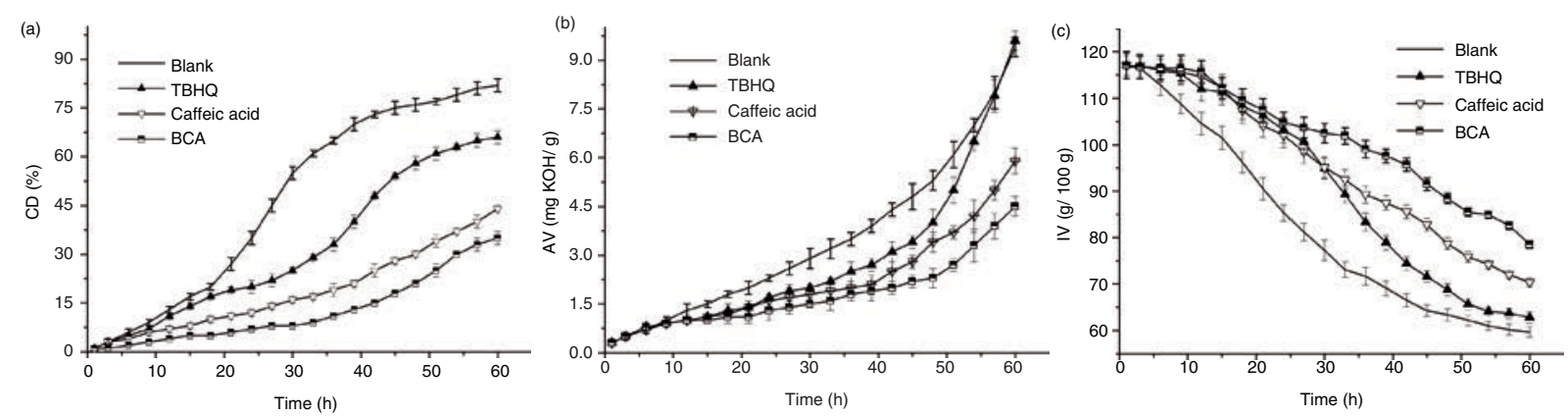

FIGURE 2. Conjugated diene values (CD), Acid values (AV) and Iodine values (IV) of antioxidants during deep frying in soybean oil (average value \pm standard deviation, $n=2$ ).

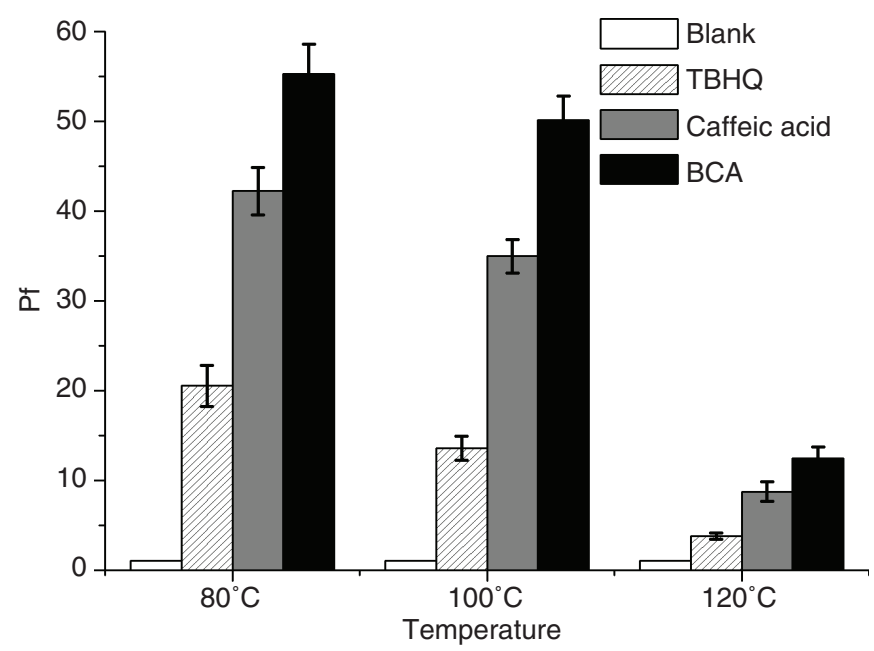

Figure 3. Pf values at concentration $0.02 \%$ at 80,100 , and $120^{\circ} \mathrm{C}$. (average value \pm standard deviation, $\mathrm{n}=2$ ). Reported data show standard deviation below $5 \%$. Statistical significance has $p$ values always below 0.05 .

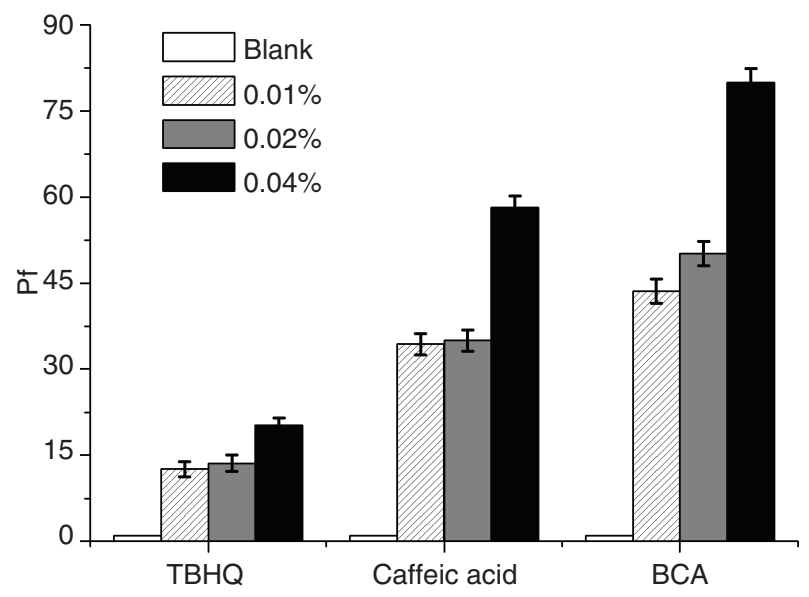

FIGURE 4. Pf values at different concentrations in lard, at $100^{\circ} \mathrm{C}$. (average value \pm standard deviation, $\mathrm{n}=2$ ). Reported data show standard deviation below $5 \%$. Statistical significance has $p$ values always below 0.05 .
Hence, BCA lasted longer in deep frying oil compared to TBHQ.

3. The influence of the catechol group: Hydrogen bonds in catechol group made the intermediate more stable after one of the phenolic hydroxyl hydrogen atoms left (Baum and Perun, 1962). Meanwhile, some metallic ions were more easily chelated than TBHQ, also by the catechol group of BCA (Cornard and Lapouge, 2006).

\subsection{DPPH radical scavenging activity}

In the DPPH system, BCA showed approximate antioxidant capacity with TBHQ, and lower capacity compared to caffeic acid:

$\boldsymbol{E C}_{50}$ values. The steric effect of the tert-butyl group hinders free radical DPPH from occupying carbon positions on the benzene ring of BCA. As a result, the 

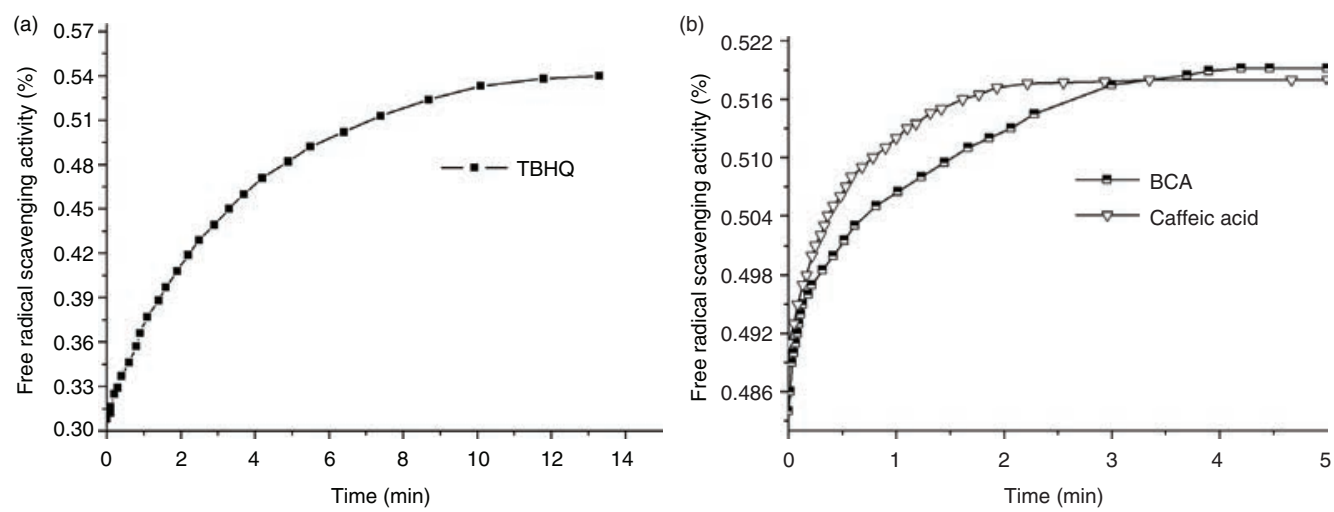

FIGURE 5. Kinetic behavior of TBHQ, caffeic acid and BCA at $\mathrm{EC}_{50}$ concentrations in DPPH.<smiles>C=CC(C)(C)c1cc(/C=C/C(=O)O)cc2c1OCO2</smiles><smiles>CCOC(=O)C1=CC(=O)C(=O)C(C(C)(C)C)=C1</smiles>

8

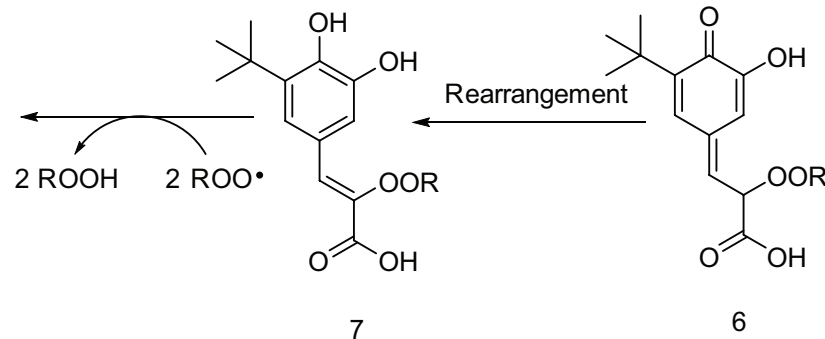

7

SCHEME 2. Elucidation of the synergistic effects of ortho-hydroxy groups on BCA.

free radical scavenging activity of BCA is less than caffeic acid and TBHQ in the DPPH system. However, the synergistic effect of the catechol group benefited the leaving out of hydrogen atoms, and the large conjugated system of the acrylic acid group enabled the stabilized radical resonance to capture more DPPH radicals, thus, making the free radical scavenging activity of BCA similar to TBHQ in the DPPH solution.

Kinetic behavior. The steric effect of the tert-butyl group on the BCA caused the second phenol hydrogen in the ortho-tert-butyl group to remain after the first one left. The same response was observed for the oxidation of compound $\mathbf{3}$ to compound $\mathbf{4}$ without protecting the phenol hydrogen.

\section{CONCLUSIONS}

The specific structure of BCA was confirmed by X-ray single crystal diffraction, ${ }^{1} \mathrm{H}$, and ${ }^{13} \mathrm{C}$ NMR. It had a higher lipophilicity than caffeic acid, and showed superior antioxidant capacity to caffeic acid and TBHQ in deep frying and Rancimat tests, but an almost equal capacity to TBHQ in the DPPH method, suggesting its potential use as an antioxidant in lipophilic conditions. Moreover, the incorporation of the tert-butyl group into the caffeic acid molecule may render additional health benefits or possible synergistic effects in vivo, which will be further investigated. 


\section{ACKNOWLEDGMENTS}

The authors thank Dr. H. M. Deng of the Analysis Center of Shanghai University for NMR spectra recording and technical assistance.

\section{REFERENCES}

Akoh CC, Min DB. 2008. Food lipids: chemistry, nutrition, and biotechnology: CRC press. https://doi. org/10.1201/9781420046649.ch27

Baum B, Perun A. 1962. Antioxidant efficiency versus structure. Polym. Eng. Sci. 2, 250-259. https://doi.org/10.1002/ pen.760020314

Cornard JP, Lapouge C. 2006. Absorption spectra of caffeic acid, caffeate and their 1:1 complex with Al (III): density functional theory and time-dependent density functional theory investigations. J. Phys. Chem. A. 110, 7159-7166. https://doi.org/10.1021/jp060147y

Chen CW, Ho CT. 1995. Antioxidant properties of polyphenols extracted from green and black teas. J. Food Lipids 2 35-46. https://doi.org/10.1111/j.1745-4522.1995.tb00028.x

Emerton V, Choi E. 2008. Essential guide to food additives. Leatherhead Food International, RSC, Cambridge, UK. https://doi.org/10.1039/9781847559234

Glende EA, Recknagel RO. 1994. 33-Spectrophotometric Detection of Lipid-Conjugated Dienes A2-Tyson, Charles A. In Vitro Toxicity Indicators, Frazier, J. M., Ed. Academic Press, inc., pp. 400-406. http://dx.doi.org/10.1016/ B978-0-08-092440-3.50039-7

Gülçin İ. 2006. Antioxidant activity of caffeic acid (3, 4-dihydroxycinnamic acid). Toxicology 217, 213-220. https://doi. org/10.1016/j.tox.2005.09.011

Handbook of Food Analysis, 2nd ed, vol 1. Marcel Dekker, Inc., New York.

Hsieh Y-TL, Regenstein JM. 1992. Storage stability of fish oil, soy oil, and corn oil mayonnaises as measured by various chemical indices. J. Aquat. Food Prod. 1, 97-106. https:// doi.org/10.1300/j030v01n01_10

Hsieh, Y-TL, Regenstein JM. 1991. Factors affecting quality of fish oil mayonnaise. J. Food Sci. 56, 1298-1301. https://doi. org/10.1111/j.1365-2621.1991.tb04757.x

Huang Y, Jiang Z, Liao X. 2014. Antioxidant activities of two novel synthetic methylbenzenediol derivatives. Czech $J$. Food Sci. 32, 348-353.

Hwang H-S, Winkler-Moser JK, Bakota EL, Berhow MA, Liu SX. 2013. Antioxidant activity of sesamol in soybean oil under frying conditions. J. Agric. Food Chem. 90, 659-666. https://doi.org/10.1007/s11746-013-2204-5

Jeong CH, Jeong HR, Choi GN, Kim DO, Lee UK, Heo HJ 2011. Neuroprotective and antioxidant effects of caffeic acid isolated from Erigeron annuus leaf. Chinese Med. 6, 25. https://doi.org/10.1186/1749-8546-6-25

Liu C, Zhao Y, Li X. 2014. Antioxidant capacities and main reducing substance contents in 110 fruits and vegetables eaten in China. Food Nutr Sci. 5, 293. https://doi. org/10.4236/fns. 2014.54036

Paquot C, Hautfenne A. 1987. Standard methods for the analysis of oils, fats, and derivatives. Analytica Chimica Acta, 7th ed, vol 201. Blackwell, Inc., Oxford, pp. 373.

Piang-Siong W, De Caro P, Marvilliers A, Chasseray X. 2017. Contribution of trans-aconitic acid to DPPH scavenging ability in different media. Food Chem. 214, 447-452. https:// doi.org/10.1016/j.foodchem.2016.07.083

Rojas M, Brewer M. 2007. Effect of natural antioxidants on oxidative stability of cooked, refrigerated beef and pork. J. Food Sci. 72, 282-288. https://doi. org/10.1111/j.1750-3841.2007.00335.x

Saiz-Poseu J, Alcón I, Alibés R. 2012. Self-assembly of alkylcatechols on HOPG investigated by scanning tunneling microscopy and molecular dynamics simulations. Cryst. Eng. Comm. 14, 264-271. https://doi.org/10.1039/c1ce06010d

Shahidi F, Janitha P, Wanasundara P. 1992. Phenolic antioxidants. Critical Reviews Food Sci. Nutrit. 32, 67-103. https:// doi.org/10.1080/10408399209527581

Silva FA, Borges F, Ferreira MA. 2001. Effects of phenolic propyl esters on the oxidative stability of refined sunflower oil. J. Agric. Food Chem. 49, 3936-3941. https://doi. org/10.1021/jf010193p

Van Esch GJ. 1986. Toxicology of tert-butylhydroquinone (TBHQ). Food Chem. Toxicol. 24, 1063-1065. https://doi. org/10.1016/0278-6915(86)90289-9

Wang Q, Yang Y, Li Y, Yu W, Hou ZJ. 2006. An efficient method for the synthesis of lignans. Tetrahedron Lett. 62, 61076112. https://doi.org/10.1016/j.tet.2006.03.111

Zhang CX, Wu H, Weng XC. 2004. Two novel synthetic antioxidants for deep frying oils. Food Chem. 84, 219-222. https:// doi.org/10.1016/s0308-8146(03)00205-x

Zhou LL, Li C, Weng XC. 2016. A novel method for quantitative analysis of acetylacetone and ethyl acetoacetate by fluorine-19 nuclear magnetic spectroscopy. Magn. Reson. 54, 222-226. https://doi.org/10.1002/mrc.4369

Zuta P, Simpson B, Zhao, X, Leclerc L. 2007. The effect of $\alpha$-tocopherol on the oxidation of mackerel oil. Food Chem. 100, 800-807. https://doi.org/10.1016/j. foodchem.2005.11.003 